\title{
Analyzing E-Commerce Success using DeLone and McLean Model
}

\author{
Ruth Johana Angelina ${ }^{1)^{*}}$, Aji Hermawan ${ }^{2)}$, Arif Imam Suroso ${ }^{3)}$ \\ ${ }^{122) 33}$ School of Business IPB University, Indonesia \\ Jl. Raya Pajajaran Babakan, Bogor Tengah, Bogor \\ ${ }^{1)}$ ruthjohana.rj@gmail.com, ${ }^{2)}$ ajiher@ipb.ac.id, ${ }^{3)}$ imamsuroso@gmail.com
}

Article history:

Received 9 June 2019

Revised 13 September 2019

Accepted 17 September 2019

Available online 28 October 2019

\section{Keywords:}

DeLone and McLean model,ECommerce Success, Information System Success Measurement, IS Success Model

\begin{abstract}
Background: The increasing usage and development of e-commerce in Indonesia, demands competition between e-commerce that exists. To be successful e-commerce should be balanced with a good information system. Some clinical research has established what factors that affected the success, including DeLone and McLean. According to their e-commerce success model, there are six variables that affect e-commerce success, system quality, information quality, service quality, use, user satisfaction, and net benefit

Objective: The study aims to analyze the relationship between system quality, information quality and service quality to user satisfaction and use. In addition, the study aims to analyze the relationship between user satisfaction and use to a net benefit.

Methods: This study draws on the DeLone and McLean Model of Information System (IS) success model. It is a quantitative study that was conducted in the form of a survey of 110 users of each Lazada, Bukalapak, and Shopee users.

Results: By applying DeLone and McLean model, this findings confirmed four hypotheses were significant in Bukalapak, Lazada, and Shopee.

Conclusion:There were significant effect between the system quality on user satisfaction, service quality on use, service quality on user satisfaction and user satisfaction on net benefits. Meanwhile, system quality had insignificant effect to use and also information quality to use in Bukalapak, Lazada, and Shopee.
\end{abstract}

\section{INTRODUCTION}

The era of globalization has provided many conveniences for humans in carrying out daily activities. One of the conveniences provided is the presence of sophisticated information technology that is able to complement human needs. E-government, e-commerce, e-education, e-laboratory and other things based on electronics are the example of the development of technology. E-commerce, according to Laudon \& Traver[1], means using the internet and web for business purposes and it will possibly make a commercial transaction between organization and individual. Based on the results released by Wearesocial about Global Digital Report 2018 [2], from 265 billion Indonesians, almost 132 billion people use the internet in their daily activities. From all of the total internet users, around 28.07 million people transacted to meet their needs through e-commerce. According to the results of Wearesocial, people are more interested in the fashion category, followed by travel, hobbies, furniture, electronics, video games, food, and digital music.

The increasing usage and development of e-commerce in Indonesia, demand competition between e-commerce that exists. One of the successful keys to e-commerce is the information system. Successful e-commerce should be balanced with a good information system (IS) because without it, there would be no transaction. They need to know what factors of the information systems that become a key to be successful e-commerce and identify the relationship between all variables that make a good IS. In 1992, the information systems success model used as a framework and model for measuring the complex dependent variable in IS research was presented by DeLone and McLean [3]. Ten years later, in 2003, they [4] proposed enhancement in the original model by doing research that apply and validate, the model. Based on the research, minor refinements had proposed to the model and updated DeLone and McLean

\footnotetext{
${ }^{*}$ Corresponding author
} 
IS success model. The updated model was intended to measure e-commerce system success and give recommendations regarding current and future measurement of IS success. Therefore, in this research, the author used DeLone and McLean model [4] to measure information system of e-commerce.

According to DeLone and McLean model, there were six variables that affect e-commerce success namely system quality, information quality, service quality, use, user satisfaction, and net benefit. So, the purpose of this research is to analyze the relationship between system quality, information quality and service quality to user satisfaction and use. In addition, the study aims to analyze the relationship between user satisfaction and use to a net benefit. This research was conducted on three e-commerce, Lazada, Bukalapak, and Shopee because they are in the top five ecommerce in Indonesia, according to iprice [5]. Previously, there had never been a study comparing three ecommerce at once. This paper is organized as follows: section 2 is the literature review, section 3 is method, section 4 is the result, section 5 is discussion, and the last section is conclusions.

\section{LITERATURE REVIEW}

\section{A. E-commerce}

E-commerce is a tangible form of progress in information systems technology in Indonesia. Information systems technology itself, consists of 3 elements, namely system elements, technology elements and information elements. System elements are defined by Wilkinson et al [6] as a group that interacts in a shared function to achieve the stated goals. The system coordinates the resources needed to convert inputs into outputs. The second element is the technology. According to Jogiyanto [7], technology can be grouped into two categories, namely computer system technology (hardware and software) and telecommunications system technology. The third element is information. Information according to Wilkinson et al [6] is a collection of data that has been transformed and become more valuable or meaningful in a particular process. Information systems technology has five main roles in the organization [7], namely: efficiency, effectiveness, communication, collaboration, competitive. Reflecting on the importance of this role, this study further researching information systems in e-commerce.

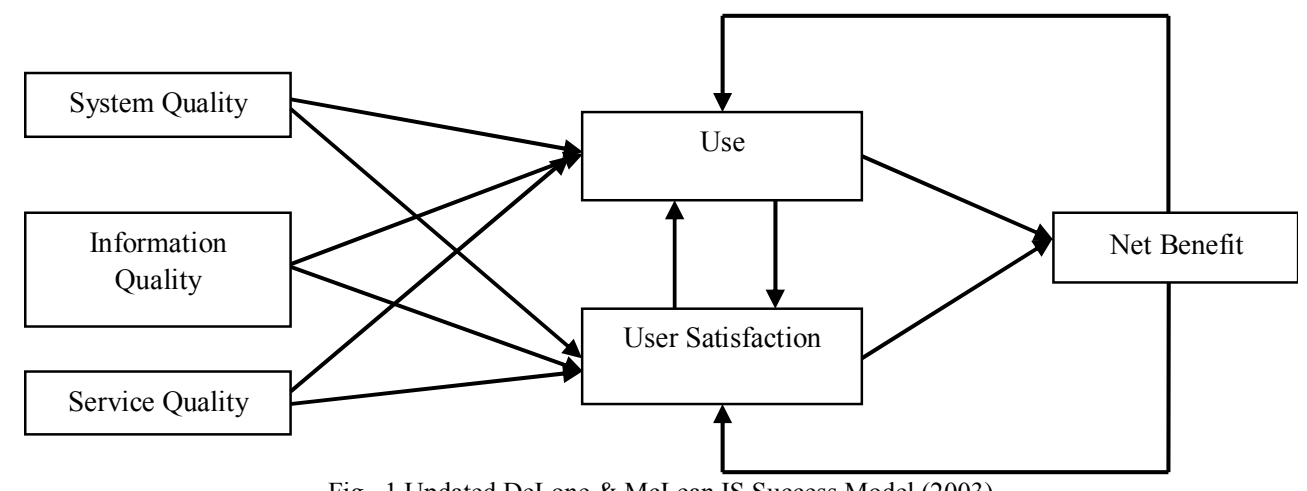

Fig. 1 Updated DeLone \& McLean IS Success Model (2003)

\section{B. DeLone \& McLean IS Success Model}

DeLone and McLean [3] reviewed the prior research during the period 1981-1987 and created the taxonomy of IS success based on this review. In 1992, six variables of IS success were identified, namely system quality, information quality, use, user satisfaction, individual impact, and organizational impact. However, these are not independent but interdependent. This model is based on previous research on the communication theory of Shannon \& Weaver [8] which states that technical levels explain how information can be produced from the accuracy and efficiency of the system, the semantics level measured the success in delivering information. Mason [9] introduced a theory called the Information "Influence" Theory whose emphasis is on the influence of information. Mason, then replaced the term effectiveness with influence. This level of influence contains the sequence of events of influence, namely receipt of information (receipt), influence on recipient and influence on the system. This model was then applied by DeLone and McLean to yield six variables or aspects of information systems. They are system quality, information quality, use, user satisfaction, individual impact, and organizational impact. After the publication of the success model by DeLone and McLean [3], many IS researchers modified the model. In 2003, service quality had 
been added by DeLone and McLean [4] to the updated model of IS success and the individual and organizational impact were replaced into net benefit. Fig 1 shows the updated model of IS success.

\section{Prior Research}

E-commerce system should have characteristics which were defined by system quality and the content issue were captured by information quality [4]. Both system quality and information quality indirectly impact IS success, predominantly through user satisfaction. According to Freeze et al [10], it is important to provide users with up-todate information and relevant, through a user-friendly and interactive system. The influence of information quality to IS success is very strong. The information should be complete, understandable, secure and accurate to increase system use and user satisfaction [11]. Michel \& Cocula [12] said that system quality and service quality have a significant influence on information quality which, in turn, has a significant influence on user satisfaction. In addition, Kim et al [13] had proven system quality, information quality and service quality have a significant effect on users through user satisfaction and system use. Chong et al [14] stated that system quality is the least influential among the three constructions and user satisfaction has more significant effect to net benefits than system use.

\section{METHODS}

This research has been conducted in four steps, summarized as follows:

\section{A. Defining variables and indicators}

This research was conducted on three e-commerce: Lazada, Bukalapak, and Shopee. There were six variables used to measure IS success model, namely system quality (SyQ), information quality (IQ), service quality (SeQ), use(U), user satisfaction (US) and net benefit (NB). Each variable was divided into several indicators and there was a total of 22 indicators. The variables and indicators used in this study is presented in Table 1.

TABLE 1

VARIABLES AND INDICATORS OF THIS STUDY

\begin{tabular}{lll}
\hline \hline \multicolumn{1}{c}{ Variables } & & Indicators \\
\hline \multirow{4}{*}{ System Quality (SyQ) } & SyQ1 & Flexibility \\
& SyQ2 & Security \\
& SyQ3 & Reliability \\
& SyQ4 & Response Time \\
& SyQ5 & Ease of Use \\
& IQ1 & Completeness \\
Information Quality (IQ) & IQ2 & Understandability \\
& IQ3 & Relevance \\
& IQ4 & Accuracy \\
Service Quality (SeQ) & SeQ1 & Assurance \\
& SeQ2 & Empathy \\
Use (U) & SeQ3 & Responsiveness \\
& U1 & Nature of Use \\
& U2 & Amount of Use \\
User Satisfaction (US) & US1 & Repeat Purchases \\
& US2 & Meets Customer Needs \\
& US3 & E-Loyalty \\
Net Benefit (NB) & US4 & Satisfaction \\
& NB1 & Cost Savings \\
& NB2 & Time Savings \\
& NB3 & Productivity \\
& NB4 & Effectiveness \\
\hline
\end{tabular}

\section{B. Defining sample and distributing the questionnaire}

The authors used Purposive Sampling method to get the sample. Total population of respondents in this research was unlimited, the sample was obtained using Hair et al theory [15]. He recommended the total minimal sample is five times total indicators, which is 110 sample for each e-commerce. At this stage, the data were collected by distributing the questionnaire to Lazada, Bukalapak or Shopee users via Google form. There were a total of 330 respondents. The questionnaire used a Likert scale with a scale of strongly disagree (1), disagree (2), no choice (3), agree (4), strongly agree (5). 


\section{Testing Fit}

After the data were obtained from the questionnaire, data were tested for validity and reliability first. According to Joreskog and Sorborn [16], CFA is used to test the validity and reliability of the model. In this study, the validity test was carried out using CFA (Confirmatory Factor Analysis) and reliability using Construct Reliability (CR) and Varianced Extracted (VE) values. Data were also tested by seeing Goodness of Index to ensure the data fit the model.

\section{Hypothesis testing}

After testing the validity and reliability of each variable, the Latent Variable Score (LVS) value will be sought. The purpose of this LVS value is to simplify the model because of the limitation of the total sample [17]. After obtaining a latent variable score for each variable, the value were reprocessed using SEM (Structured Equation Modeling) as in Fig 2. This path diagram is adopting the updated DeLone and Mclean IS success model by taking several dimensions or hypothesis. After all data of three e-commerce had been processed, then the author analyzed and compared the result of all hypothesis $\left(\mathrm{H}_{1}-\mathrm{H}_{8}\right)$. The hypothesis to be tested, such as:

$\mathrm{H}_{1}=$ System quality has significant effect on use

$\mathrm{H}_{2}=$ System quality has significant effect on user satisfaction

$\mathrm{H}_{3}=$ Information quality has significant effect on use

$\mathrm{H}_{4}=$ Information quality has significant effect on user satisfaction

$\mathrm{H}_{5}=$ Service quality has significant effect on use

$\mathrm{H}_{6}=$ Service quality has significant effect on user satisfaction

$\mathrm{H}_{7}=$ Use has significant effect on net benefit

$\mathrm{H}_{8}=$ User satisfaction has significant effect on net benefit

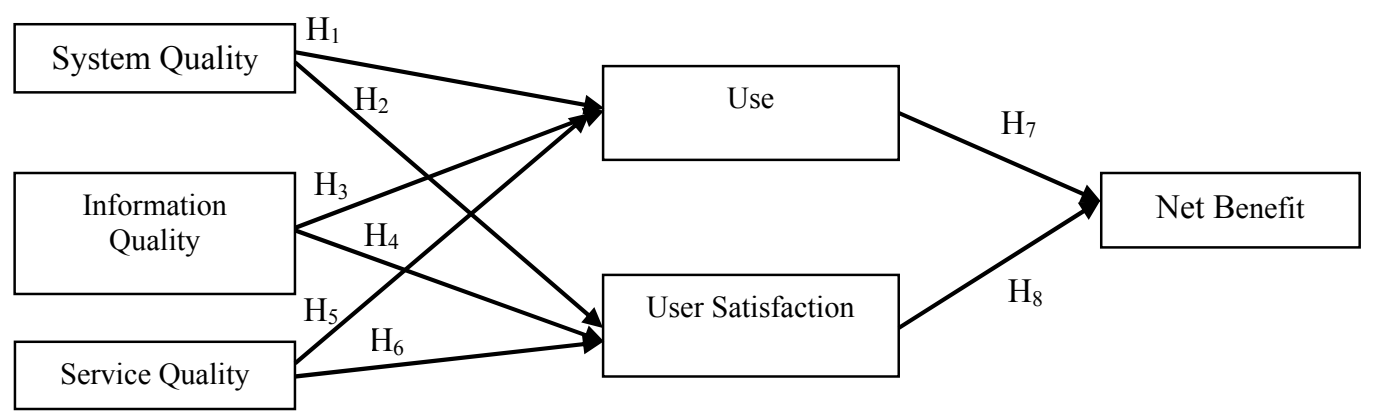

Fig 2. Path Diagram

\section{RESULTS}

The measurement was done by using SEM. Table 2 presented Goodness of Fit (GOF) Index value for Lazada Bukalapak and Shopee, mostly the value shown good fit.

TABLE 2

GOODNESS OF FIT INDEX

\begin{tabular}{|c|c|c|c|c|c|c|c|}
\hline GoF Index & & Cut off Value & & zada & Bukalap & & Shopee \\
\hline$R M R$ & $\leq 0.1$ & 0.023 & Good Fit & 0.027 & Good Fit & 0.044 & Good Fit \\
\hline RMSEA & $\leq 0.08$ & 0.091 & Marginal Fit & 0.08 & Good Fit & 0.16 & Poor Fit \\
\hline$N F I$ & $\geq 0.90$ & 0.99 & Good Fit & 0.99 & Good Fit & 0.98 & Good Fit \\
\hline$N N F I$ & $\geq 0.90$ & 0.98 & Good Fit & 0.98 & Good Fit & 0.92 & Good Fit \\
\hline$C F I$ & $\geq 0.90$ & 1 & Good Fit & 1 & Good Fit & 0.98 & Good Fit \\
\hline$I F I$ & $\geq 0.90$ & 1 & Good Fit & 1 & Good Fit & 0.98 & Good Fit \\
\hline$R F I$ & $\geq 0.90$ & 0.96 & Good Fit & 0.97 & Good Fit & 0.9 & GoodFit \\
\hline$G F I$ & $\geq 0.90$ & 0.98 & Good Fit & 0.98 & Good Fit & 0.97 & Good Fit \\
\hline$A G F I$ & $\geq 0.90$ & 0.88 & Marginal Fit & 0.89 & Marginal Fit & 0.77 & Poor Fit \\
\hline
\end{tabular}


After validating data, this study compared the results of the SEM. Table 3 presented the comparison of ecommerce successful model by using DeLone and McLean model.

TABLE 3

COMPARISON OF E-COMMERCE SUCCESSFUL MODEL

\begin{tabular}{llll}
\hline \hline Hypothesis & Lazada & Bukalapak & Shopee \\
\hline SyQ $\rightarrow$ U $\left(\mathrm{H}_{1}\right)$ & Not Significant & Not Significant & Not Significant \\
SyQ $\rightarrow$ US $\left(\mathrm{H}_{2}\right)$ & Significant & Significant & Significant \\
$\mathrm{IQ} \rightarrow \mathrm{U}\left(\mathrm{H}_{3}\right)$ & Not Significant & Not Significant & Not Significant \\
$\mathrm{IQ} \rightarrow \mathrm{US}\left(\mathrm{H}_{4}\right)$ & Significant & Not Significant & Significant \\
$\mathrm{SeQ} \rightarrow \mathrm{U}\left(\mathrm{H}_{5}\right)$ & Significant & Significant & Significant \\
$\mathrm{SeQ} \rightarrow \mathrm{US}\left(\mathrm{H}_{6}\right)$ & Significant & Significant & Significant \\
$\mathrm{U} \rightarrow \mathrm{NB}\left(\mathrm{H}_{7}\right)$ & Not Significant & Significant & Not Significant \\
$\mathrm{US} \rightarrow \mathrm{NB}\left(\mathrm{H}_{8}\right)$ & Significant & Significant & Significant \\
\hline
\end{tabular}

\section{DISCUSSION}

The results indicated that the system quality of Lazada, Bukalapak, and Shopee had no significant effect on their system use. The hypotheses $\mathrm{H}_{1}$ was then rejected. This result was the same with the research conducted by Chong et al [14] which stated that system quality had no significant relationship to use. This can occur due to a factor of trust. Although e-commerce has deficiencies in system quality but it has no significant impact on the use of e-commerce because of trust. Meanwhile, the results of other studies conducted by Venkatesh et al [18] showed that the relationship of system quality to use can be influenced by the system's novelty. Research conducted by Marjanovic et al [19] also showed that the relationship between system quality and use can be significantly influenced by factors from the information system development team on e-commerce internal. For example, every e-commerce development team must be able to see new potentials that can increase the success of e-commerce, so that the system can continue to grow and use level will increase.

Based on this research, the system quality of Bukalapak, Lazada and Shopee had a significant effect on user satisfaction, so the hypothesis $\mathrm{H}_{2}$ was accepted. This result is in accordance with the research conducted by McGill et al [20] where system quality affected user satisfaction significantly. His research stated that the more e-commerce being used, usually followed by the more benefits users get from e-commerce. It means that e-commerce Lazada, Bukalapak and Shopee being very useful in users' life. Other research conducted by Nirwanto \& Andarwati [21] stated that the factors that cause system quality had significantly affected user satisfaction are convenience and integrated systems. As we known, this e-commerce have grown very fast and they become more integrated in their system, which is very useful and helpful for users. Seddon and Kiew [22] also stated that user satisfaction is the result of the interpretation of information quality, system quality, and usability. On the other hand, the effect of system quality on user satisfaction can be insignificant because of the presence of work procedure factors that are inherent in the user [23].

This research has resulted that the information quality on Lazada, Bukalapak, and Shopee had no significant effect on use, so hypothesis $\mathrm{H}_{3}$ was rejected. This result is in accordance with the research conducted by Khayun et al [24] where the information quality had no significant effect on use but had an effect on user satisfaction which in turn will affect use. The more satisfied users of Lazada, Bukalapak and Shopee, the system use will also increase. This is also confirmed by research conducted by Baron \& Kenny [25] where information quality had indirectly affected use through user satisfaction. McGill et al [20] study also stated that there are indirect effects of information quality through user satisfaction with use. The insignificant influence between the information quality on use can also be caused by the existence of mandatory nature of the system use, as expressed by Goodhue \& Thomson [26] and Iivari [27]. Meanwhile, according to Rai et al [28], there was significant influence between information quality to use, when measured from system dependence. If the user feels a dependence on an information system, this will cause the use level to increase. Research conducted by Wang et al [29] stated that the information quality can have a significant effect on use because of the trust factor. The existence of trust factors can increase the intensity of use.

This study showed the information quality of Shopee and Lazada significantly influence user satisfaction while the information quality at Bukalapak did not significantly influence user satisfaction. Research on the information quality that has a significant effect on user satisfaction was shown by McGill et al [20] which stated that information quality had a significant effect on user satisfaction. A clearer understanding of users will increase user satisfaction with the information provided. In addition, research conducted by Palmer [30] stated that there was significant effect of information quality on user satisfaction caused by the fulfillment of the quality aspects of a website such as the content and layout of the website. If users paid attention to the layout of the website, Bukalapak seemed to be common rather than Lazada and Shopee which were more interesting from the colour and layout. On the other hand, 
the research conducted by Widodo et al [31] stated that the quality of information did not have a significant effect on user satisfaction because of the trust factor. Trust factor will make users stay on using e-commerce, despite their shortcomings.

Service quality is the users' perception of the services provided by service providers, in this case, the third ecommerce. The results obtained that service quality in Bukalapak, Shopee, and Lazada had a significant effect on its use, so hypothesis $\mathrm{H}_{5}$ was supported. Based on research conducted by Wang et al [29], trust is become the factor that service quality had a significant effect on use. This belief will later have a positive impact on use. In addition, research conducted by Hussein \& Selamat [32] also stated that service quality had a significant positive effect on use due to service / IT Support / Customer Care factors that have good and experienced ability to resolve user complaints. As we known, Lazada, Bukalapak and Shopee have Customer Care support that can be reached in 24hours/7 days and they are ready to help users.

In addition, the service quality for each e-commerce had a significant effect on user satisfaction, so $\mathrm{H}_{6}$ was supported. Research conducted by Shaw et al [33] supports this research, where service quality had a significant influence on user satisfaction because of the good response time of the support team so as to increase the satisfaction of users. Other research conducted by Coombs et al [34] also mentioned a significant influence, and this was due to the presence of friendly support staff so that users become more comfortable when using information systems.

This study shows that the use variables at Bukalapak had a significant effect on net benefits. It is the same with research conducted by Yuthas \& Young [35] which stated that use had a significant effect on net benefits because of the duration of the system usage. In addition, according to Halawi et al [36], use affected net benefits because of factors that increase the users' job performance. On the other hand, the use variables on Lazada and Shopee had no significant effect on net benefits. This result is the same with the research conducted by Wu and Wang [37], which showed that if there is a perceived net benefit by using e-commerce, then this will affect the use but vice versa if there is no perceived benefit then the use of the system will not be affected. Use had no significant effect on net benefit possibly because users not using e-commerce for daily life.

The results showed that user satisfaction in all three e-commerce had a significant effect on net benefits. As we know at this time, all are given access to its conveniences. Likewise, the presence of this e-commerce certainly makes the lives of users easier, more cost-effective, timesaving, productive and effective. This result is the same with the research of McGill et al [20] where the more users feel the more benefits they get, the higher the satisfaction of e-commerce users. In addition, according to Gelderman [38], this significant effect can also be influenced by the increase in performance or benefits obtained by user.

\section{CONCLUSIONS}

Based on this research, by using DeLone and McLean model, there were significant effect between the system quality on user satisfaction, service quality on use, service quality on user satisfaction and user satisfaction on net benefits in Bukalapak, Lazada and Shopee. On the other hand, there were insignificant effect on system quality on use and information quality on use in Bukalapak, Lazada, and Shopee. In addition, information quality has significant effect on user satisfaction in Lazada and Shopee, but not in Bukalapak. Besides, there was insignificant effect between use to net benefit in Lazada and Shopee, but not in Bukalapak. For further research, it is expected to compare more than 3 e-commerce with a larger sample of respondents and can be seen the tendency of each category of respondents in the use of e-commerce such as gender. In addition, further proof can be made, whether the trust factor makes no influence between the system quality on the system use in e-commerce in Indonesia. This also can be applied to factors that have previously been mentioned in the discussion section for each hypothesis.

\section{REFERENCES}

[1] K. C. Laudon, C. G. Traver. Ecommerce 2012 business. Eighth Edition. United States : Pearson, 2012.

[2] Simon. Digital In 2018: World's Internet Users Pass The 4 Billion Mark. Wearesocial.com. [Online] January 30, 2018. [Cited: October 13, 2018.] https://wearesocial.com/blog/2018/01/global-digital-report-2018.

[3] W. DeLone, E. McLean. Information systems success: the quest for the dependent variable. Information Systems Research. 1992, Vol. 3, pp. $60-95$.

[4] W. DeLone, E. McLean. The DeLone and McLean Model of Information Systems Success: A Ten-Year Update. Journal of Management Information Systems. 2003.

[5] A. S.Wardani Ini 5 e-commerce Paling Top di Indonesia Versi iPrice, Siapa Saja? Liputan6.com. [Online] July 12, 2018. [Cited: September 13, 2018.] https://www.liputan6.com/tekno/read/3585699/ini-5-e-commerce-paling-top-di-indonesia-versi-iprice-siapa-saja.

[6] J. W. Wilkinson, M. J. Cerullo, V. Raval, B. Wong-On-Wing. Accounting Information System. 4. New York : John Wiley and Sons Inc., 2000 . 
[7] Jogiyanto. Sistem Teknologi Informasi, Pendekatan Terintegrasi: Konsep Dasar, Teknologi, Aplikasi, Pengembangan dan Pengelolaan. Yogyakarta : Andi Offset, 2003.

[8] C. E. Shannon, W. Weaver. The Mathematical Theory of Communication. Urbana : University of Illinois Press, 1949.

[9] R.O. Mason. Measuring Information Output: A Communication Systems Approach. Information \& Management. 5, 1978, Vol. 1, pp. 219234.

[10] R. D. Freeze, K. A. Alshare, P. L. Lane, H. J. Wen. IS success model in E-learning context based on students' perceptions. Journal of Information Systems Education. 2010, Vol. 21, 2, pp. 173-184.

[11] A. N. H.Zaied. An integrated success model for evaluating information system in public sectors. Journal of Emerging Trends in Computing and Information Sciences. 2012, Vol. 3, 6, pp. 814-825.

[12] S. Michel, F. Cocula. Impact of the three IS qualities on user satisfaction in an information-intensive sector. Electronic Journal of Information Systems Evaluation. 2017, Vol. 20, 2, pp. 85-101.

[13] C. Kim, In-Seok Lee,Tao Wang, M. Mirusmonov. Evaluating effects of mobile CRM on employees' performance. Industrial Management \& Data Systems. 2015, Vol. 115, 4, pp. 740-764.

[14] H. Chong, D. Cates, R. Rauniar. Validity of DeLone and mclean's E-commerce model in B2C student loan industry. Journal of International Technology and Information Management. 2010, Vol. 19, 1.

[15] Hair, Jr et.al.Multivariate Data Analysis. 7th Edition. United States : Pearson, 2010.

[16] K.G Joreskog, D. Sorbom.Lisrel 8:Structural Equation Modeling With The Simplis Command Language. Chicago : SSI Inc, 1993.

[17] S.H.Wijanto, Structural Equation Modeling dengan Lisrel 8.8. Yogyakarta : Graha Ilmu, 2008.

[18] V. Venkatesh, Fd Davis. A model of the antecedents of perceived ease of use: development and test. Decision Sciences. 1996, Vol. 27, 3, pp. 451-481.

[19] U. Marjanovic, M. Delic, B. Lalic. Developing a model to assess the success of e-learning systems: Evidence from a manufacturing company in transitional economy. Information Systems and eBusiness Management. 2016, Vol. 14, 2, pp. $253-272$.

[20] T. McGill, V. Hobbs, J. Klobas. User-developed applications and information systems success: A test of DeLone and McLean's model. Information Resources Management Journal. 2003, Vol. 16, 1, pp. 24-45.

[21] N. Nirwanto, M. Andarwati. End-user satisfaction as an impact of the system quality, information quality, and top management support, upon the perceived usefulness of technology utilization. Journal of Marketing Development and Competitiveness. 2019, Vol. 13, 1, pp. 5975.

[22] P. Seddon, M. Y.Kiew. A partial test and development of DeLone and McLean's model of IS success. Australian Journal of Information Systems. 1996, Vol. 4, 1, pp. 90-109.

[23] G. Premkumar, K. Ramamurthy, S. Nilakanta. Implementation of electronic data interchange: An innovation diffusion perspective: JMIS. Journal of Management Information Systems. 1994, Vol. 11, 2, p. 157.

[24] V. Khayun, P. Ractham,D. Firpo. Assessing E-Excise Sucess With DeLone And Mclean's Model. The Journal of Computer Information Systems. 2012, Vol. 52, 3, pp. 31-40.

[25] R.M. Baron, D. A Kenny. The moderator-mediator variable distinction in social psychological research:Conceptual, strategic, and statistical considerations. Journal of Personality and Social Psychology. 1986, Vol. 51, pp. 1173-1182.

[26] D. Goodhue, R. Thompson. Task-technology fit and individual performance. MIS Quarterly. 1995, Vol. 19, 2, pp. $213-236$.

[27] J. Iivari. An empirical test of the DeLone-McLean model of information system success. Database for Advances in Information Systems. 2005, Vol. 36, 2, pp. 8-27.

[28] A. Rai, SS. LANG, RB. WELKER. Assessing the validity of IS success models: an empirical test and theoretical analysis. Information Systems Research. 2002, Vol. 13, 1, pp. 5-69.

[29] T. Wang, Y. Cao, S. Yang. Building the model of sustainable trust in e-government. 2nd IEEE international conference on information and financial engineering. 2010, pp. 698-701.

[30] J.W. Palmer. Web site usability, design and performance metrics. Information Systems Research. 2002, Vol. 13, 1, pp. $151-167$.

[31] A. Widodo, H.R.D. Putranti, Nurchayati. Pengaruh Kualitas Sistem Aplikasi dan Kualitas Informasi Terhadap Kepuasan Pengguna Sistem Aplikasi Rts (Rail Ticketing System) Dengan Kepercayaan Sebagai Variabel Mediasi. Media Ekonomi dan Manajemen. 2016, Vol. 31, 2, pp. 160-181.

[32] R. Hussein, A.K. Nor Shahriza, M.H Selamat. The impact of technological factors on information systems success in the electronicgovernment context. Business Process Management Journal. 2007, Vol. 13, 5, pp. 613-627.

[33] N. Shaw, W. DeLone, F. Niederman. Sources of dissatisfaction in end-user support: an empirical study. The DATA BASE for Advances in Information Systems. 2002, Vol. 33, 2, pp. 41-56.

[34] C. Coombs, N. Doherty, J. Loan-Clarke. The importance of user ownership and positive user attitudes in the successful adoption of community information systems. Journal of End User Computing. 2001, Vol. 13, 4, pp. 5-16.

[35] K. Yuthas, S. Young. Material matters: assessing the effectiveness of materials management IS. Information \& Management. 1998, Vol. 33, 3, pp. 115-124.

[36] L. Halawi, R. Mccarthy, J Aronson. An empirical investigation of knowledge-management systems' success. The Journal of Computer Information Systems. 2007, Vol. 48, 2, pp. 121-135.

[37] J.H. Wu, Y.M Wang. Measuring KMS success: a respecification of the DeLone and McLean model. Information \& Management. 2006, Vol. 43, 6, pp. 728-739.

[38] M. Gelderman. The relation between user satisfaction, usage of information systems and performance. Information \& Management. 1998, Vol. 34, 1, pp. 11-18. 